\title{
REFERENCES
}

Abderhalden, E. \& Blumberg, P. (1910). Hoppe-Seyl. Z. 65, 318.

Astle, M. J. \& McConnell, W. V. (1943). J. Amer. chem. Soc. $65,35$.

Brdička, R. (1933a). Coll. Trav. chim. Tchécosl. 5, 112.

Brdička, R. (1933b). Coll. Trav. chim. Tchécosl. 5, 148.

Brdickka, R. (1934). Biochem. Z. 272, 104.

Brdiěka, R. (1936). Coll. Trav. chim. Tchécosl. 8, 366.

Brdicka, R. (1947). Research, 1, 25.

Fankuchen, I. (1945). Advanc. Protein Chem. 2, 387.

Herles, F. \& Vancura, A. (1932). Bull. int. Acad. Prague, no. 42.

Heyrovský, J. \& Babička, J. (1930). Coll. Trav. chim. Tchécosl. 2, 370.
Jurka, E. (1939). Coll. Trav. chim. Tchécosl. 11, 243.

Kirkpatrick, H. F. W. (1947). Quart. J. Pharm. 20, 87.

Langmuir, I. (1918). J. Amer. chem. Soc. 40, 1361.

Millar, G. J. (1953). Biochem. J. 53, 393.

Müller, O. H. (1944). J. Amer. chem. Soc. 66, 1019.

Northrop, J. H., Kunitz, M. \& Herriott, R. M. (1948). Crystalline Enzymes, 2nd ed. New York: Columbia University Press.

Stern, K. J. \& White, A. (1938). J. biol. Chem. 122, 371.

Tristram, G. R. (1949). Advanc. Protein Chem. 5, 83.

Tropp, C., Jühling, L. \& Geiger, F. (1939). Hoppe-Seyl. Z. 262, 225.

\section{Studies on the Polarography of Proteins}

\section{THE INFLUENCE OF $\mathrm{pH}$ AND CONCENTRATIONS OF AMMONIA AND AMMONIUM ION UPON THE POLAROGRAPHIC WAVES}

\author{
By G. J. MILLAR \\ Department of Physiology, University of Saskatchewan, Saskatoon, \\ Saskatchewan, Canada
}

(Received 29 March 1952)

If a protein is dissolved in a simple buffer, the polarogram of the system consists of a single large catalytic wave known as the 'prenatrium' wave (Heyrovský \& Babička, 1930). Brdička (1933a) reported that if the protein was in an ammoniacal cobalt solution, the protein produced two waves which followed the cobalt reduction step. Later, Jurka (1939) found that the complete polarogram in ammoniacal cobalt solutions consisted of three waves which are referred to here as waves I, II and III respectively. Wave III has the same characteristics as the 'prenatrium' wave. It does not require the presence of cobalt.

Brdička (1933a) tested the effect of increasing the concentration of either the ammonia, or ammonium chloride of the buffer in order to throw some light on the controlling factors of the system. When the concentration of either of these buffer components was increased, he observed enhanced protein waves. Cystine or cysteine in the same electrolyte produced a single wave at the same voltage as the second component (wave II) of the protein record, and he observed that alteration of the concentrations of the individual buffer constituents had an enhancing effect upon the amino-acid wave also (Brdička, $1933 b)$. It is evident that the changes which Brdička observed had a complicated origin since his procedure altered the $\mathrm{pH}$ of the medium as well as the concentrations of the buffer components. The present author's interest in the effect of the concentration of the buffer components arose from a desire to test the effect of the electrolyte $\mathrm{pH}$ on the polarograms of proteins. It is obvious that the two questions are linked. Brdicka (1936) studied the effect of altering the electrolyte $\mathrm{pH}$ upon the 'prenatrium' wave, but its influence upon waves I and II has not been reported.

\section{METHODS}

The polarographic instrument and proteins used are described in the previous paper (Millar, 1953). Electrolyte $\mathrm{pH}$ values were measured with a Beckman Model $\mathrm{G}$ pH meter which was provided with a type $1190 \mathrm{E}$ glass electrode for the major portion of the work. In the early experiments, portions of the solution were removed from the electrolytic cell, placed in the glass-electrode vessel for a pH determination, then returned to the cell. Later, a polarographic cell was constructed which would accommodate the $\mathrm{pH}$-meter electrodes. These were connected to the $\mathrm{pH}$ meter by 30 in. shielded leads. The following procedures were used.

(a) The $\mathrm{pH}$ of an ammonia buffer depends upon the equilibrium $\mathrm{NH}_{4}^{+} \rightleftarrows \mathrm{NH}_{3}+\mathrm{H}^{+}$so that $\left[\mathrm{H}^{+}\right]$can be maintained at a relatively constant value and various concentrations of ammonium ion and ammonia used if $\left[\mathrm{NH}_{4}^{+}\right]$and $\left[\mathrm{NH}_{8}\right]$ are maintained in constant proportion to one another by dilution of the buffer. The results reported in section $A$ were obtained with this method. $0.001 \mathrm{M}-\mathrm{CoCl}_{2}$ and $1.52 \mathrm{M}$ - 
$\mathrm{NH}_{4} \mathrm{Cl}$ were placed in the cell and $\mathrm{NH}_{3}$ gas was bubbled into the solution until the $\mathrm{pH}$ was $8 \cdot 7$. Insulin was added to a final concentration of $0.070 \mathrm{mg} . / \mathrm{ml}$. A polarogram was recorded and the cell contents were then diluted with a solution which contained insulin and $\mathrm{CoCl}_{2}$ at the above concentrations. A polarogram was recorded and further dilutions were made. In fact, the $\mathrm{pH}$ did not remain constant. It fell during the course of the experiment to a reading of 8.5 , but in the subsequent calculations of the ammonia and ammonium ion concentrations, this discrepancy has been ignored. Subsequent experiments were arranged at three other $\mathrm{pH}$ values $(9 \cdot 0,9 \cdot 3$ and $9 \cdot 5)$. At each $\mathrm{pH}$ value, the original solution was diluted in eight or nine steps.

(b) The $\mathrm{pH}$ of the electrolyte was raised by adding small volumes of $18 \mathrm{~N}-\mathrm{NaOH}$ to the cell containing protein $\left(0.070 \mathrm{mg} . / \mathrm{ml}\right.$.), $\mathrm{NH}_{4} \mathrm{Cl}(1.0 \mathrm{M})$ and $\mathrm{CoCl}_{2}$ or $\mathrm{Co}\left(\mathrm{NH}_{3}\right)_{6} \mathrm{Cl}_{3}$ $(0.001 \mathrm{M})$. The results reported in section $\mathrm{B}$ were obtained with this method. As more and more alkali is added, the ammonium ion concentration falls and the ammonia concentration rises to the same extent. The sum of the concentrations of these components remains constant. Since $\mathrm{N}_{2}$ gas must be passed through the solution after each addition of alkali to rid the solution of $\mathrm{O}_{2}$ and for purposes of stirring, there was actually a small loss of $\mathrm{NH}_{3}$, but for the present this discrepancy has not been taken into account.

(c) The $\mathrm{pH}$ of the buffer solutions was adjusted by varying the relative volumes of stock $0.4 \mathrm{M}-\mathrm{NH}_{4} \mathrm{Cl}$ and $0.4 \mathrm{M}-\mathrm{NH}_{3}$ solutions. The final solution in the cell contained $0.001 \mathrm{M}$ $\mathrm{CoCl}_{2}$ and insulin in varying amounts.

(d) The $\mathrm{pH}$ of the medium was altered by bubbling $\mathrm{NH}_{8}$ gas into a solution containing $\mathrm{NH}_{4} \mathrm{Cl}(0.5 \mathrm{M}), \mathrm{CoCl}_{2}(0.001 \mathrm{M})$ and bovine plasma albumin. The flow of gas was stopped at suitable intervals at which time the $\mathrm{pH}$ of the electrolyte was determined and a polarogram was recorded.

Preliminary experiments using procedures $(b),(c)$ and $(d)$ confirmed Brdicka's observation that wave III is diminished as the $\mathrm{pH}$ is raised (Brdicka, 1936). Waves I and II showed the reverse effect over the range of $\mathrm{pH}$ used.

\section{RESULTS}

\section{A. Experiments with varying concentration of total buffer components}

The relation between the heights of waves $I\left(H_{1}\right)$ and II $\left(H_{I I}\right)$, and the calculated concentrations of ammonia and ammonium ion can be seen in Fig. 1 which shows that if the $\mathrm{pH}$ of the medium is held fairly constant, then both waves I and II become larger when the concentrations of ammonia and ammonium ion are increased. Fig. 1 also shows that at a given concentration of ammonium ion, waves I and II become larger when ammonia is added and the $\mathrm{pH}$ is raised. On the other hand, it is evident that, at a given concentration of ammonia, the heights of these waves are increased by additions of ammonium ion. Under these circumstances the $\mathrm{pH}$ falls. The waves seem to depend upon specific properties of ammonia and ammonium ion which mask any specific $\mathrm{pH}$ effect.
The curves relating $\mathrm{H}_{\mathrm{II}}$ and $\left[\mathrm{NH}_{3}\right]$ are interesting, for, in contrast to the other families, they tend to be parallel and linear over an appreciable range.

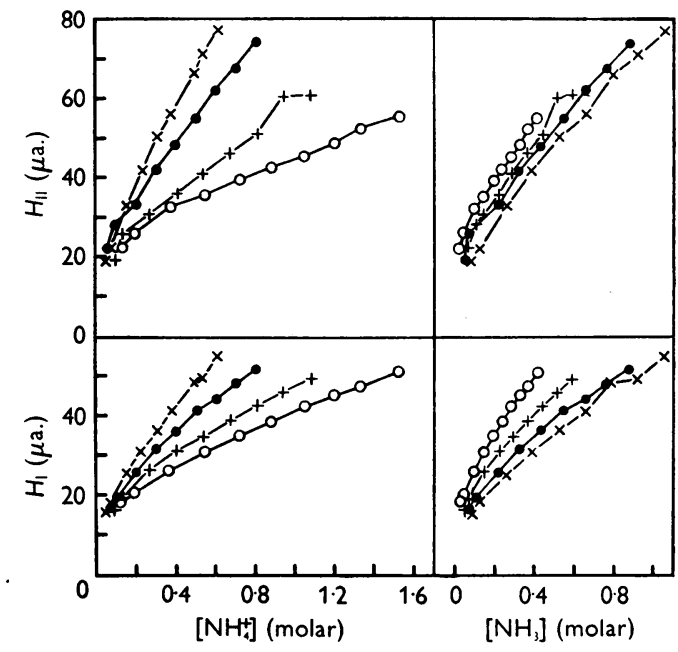

Fig. 1. The effect on waves I and II of alteration of the concentrations of ammonia and ammonium ion at relatively constant electrolyte $\mathrm{pH}$ values. Solutions contained bovine plasma albumin $\left(0.070 \mathrm{mg} . / \mathrm{ml}\right.$.), $0.001 \mathrm{M}-\mathrm{CoCl}_{2}$, $\mathrm{NH}_{3}$ and $\mathrm{NH}_{4} \mathrm{Cl}$. Initial buffer concentration was depressed by progressive dilution with a solution of albumin and $\mathrm{CoCl}_{2}$ at the concentrations indicated above. $\mathrm{pH}$ values: $\times-\times, 9 \cdot 5 ; \bigcirc-9 \cdot 3 ;+-+, 9 \cdot 0 ; \bigcirc-O, 8 \cdot 7$.

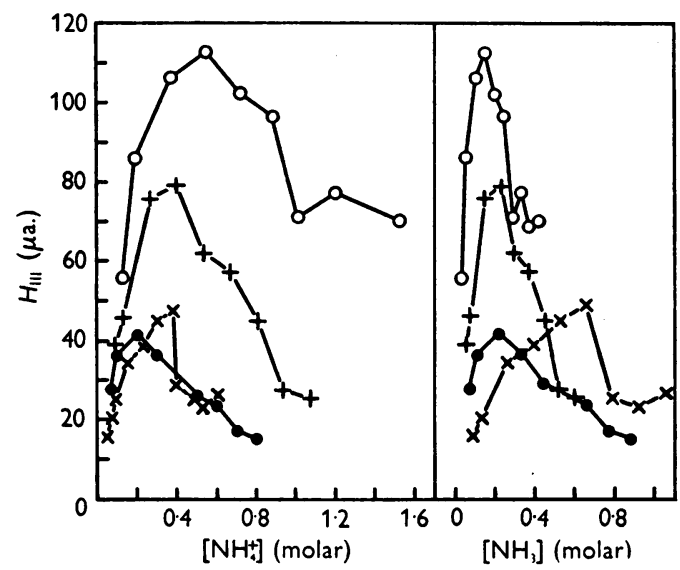

Fig. 2. The effect on wave III of alteration of the concentrations of ammonia and ammonium ion at relatively constant electrolyte $\mathrm{pH}$ values. Conditions and symbols as in Fig. 1.

Fig. 2 shows the relation between the magnitude of wave III $\left(H_{\text {III }}\right)$ and the concentrations of the buffer constituents. This wave showed a distinctly different response from those of waves I and II. The 
data are presented here in the interests of completeness, although the overall behaviour of this wave cannot be explained at the present time. As a confirmation of Brdička's work, however, it should be noted that at low molarity the height of the wave is enhanced by lowering the $\mathrm{pH}$. At a given $\left[\mathrm{NH}_{4}^{+}\right]$, a lower $\mathrm{pH}$ is produced by decreasing $\left[\mathrm{NH}_{3}\right]$, while at constant $\left[\mathrm{NH}_{3}\right]$, a lower $\mathrm{pH}$ is produced by raising $\left[\mathrm{NH}_{4}^{+}\right]$. In the range of low buffer molarity at least, wave III does not seem to be influenced by any specific effects of the individual buffer constituents, and, of the three variables, $\mathrm{pH}$ seems to influence its height most. In contrast, any effect of $\mathrm{pH}$ on waves I and II is overshadowed by the effects of the individual buffer components.

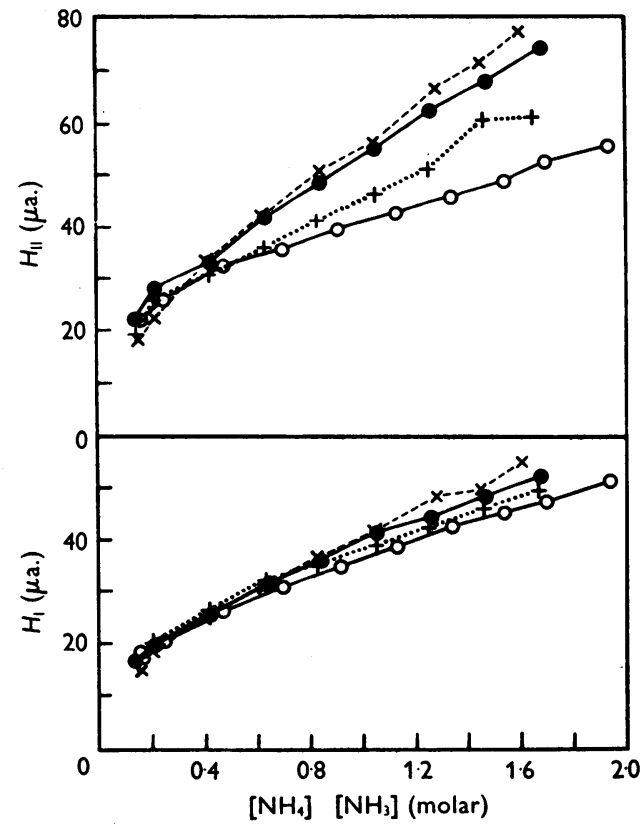

Fig. 3. The effect on waves I and II of ammonia buffer molarity at four values of electrolyte $\mathrm{pH}$. Conditions and symbols as in Fig. 1.

Since an increased concentration of either ammonia or ammonium ion has an enhancing effect on the first two waves when the other component is maintained constant, the wave heights were plotted against the sum of the concentrations of these two constituents with the result shown in Fig. 3. This arrangement of the date shows that if the $\mathrm{pH}$ of the medium is altered by varying the relative concentrations of the buffer components while the total buffer molarity is maintained constant, then waves I and II are enhanced by increasing the $\mathrm{pH}$ of the electrolyte over the range which was used in this experiment.

\section{B. Experiments with fixed concentration of total buffer components}

The results reported in section $\mathbf{A}$ suggested that the effect of $\mathrm{pH}$ on waves I and II could be investigated best under the conditions of procedure $(b)$ in which the total buffer molarity remained constant.

Fig. 4 shows the results of an experiment where the initial solution contained $\mathbf{M}$-ammonium chloride, 0.001 M-cobaltous chloride and crystalline chymotrypsin at a concentration of $0.070 \mathrm{mg} . / \mathrm{ml}$. Wave heights were measured for waves I, II and II min. The corresponding $\mathrm{pH}$ curves when the wave heights are plotted against $\mathrm{pH}$ are labelled $H_{\mathrm{I}}, H_{\mathrm{II}}$ and $H_{\mathrm{II} \text { min. }}$ in accordance with the terminology used previously (Millar, 1953). To record a polarogram at pH $3 \cdot 73$, a small volume of concentrated hydrochloric acid was added to the solution. All other $\mathrm{pH}$ values were obtained by adding small volumes of $18 \mathrm{~N}$-sodium hydroxide solution. All three curves have a positive slope as the $\mathrm{pH}$ of the medium is raised from $3 \cdot 73$ to about $8 \cdot 6$, after which they rise

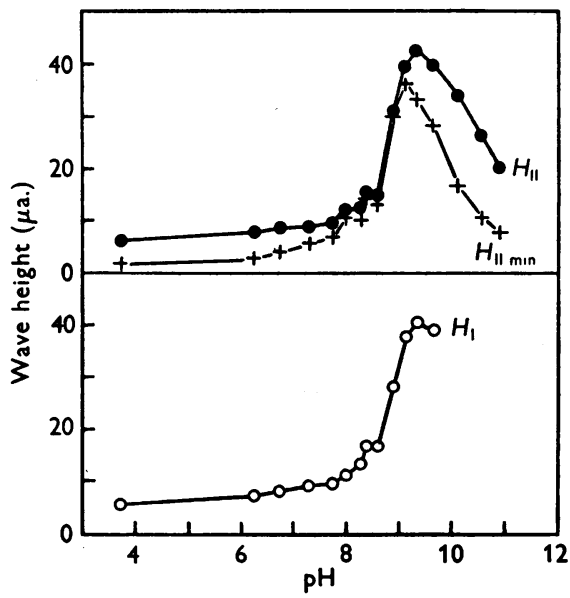

Fig. 4. Effect of electrolyte $\mathrm{pH}$ on the polarographic waves of chymotrypsin. For conditions see text.

rapidly to a maximum value, then fall. The curve for $H_{\mathrm{I}}$ is incomplete because wave II was so large that wave I could not be distinguished properly. Similar pH curves were obtained with insulin, pepsin, and bovine plasma albumin. The $\mathrm{pH}$ curves of all the proteins showed the series of changes which are seen in Fig. 4, but the response of each protein differed from the response of the others in two respects. The magnitude of a given wave at a given $\mathrm{pH}$ value varied from protein to protein and the $\mathrm{pH}$ at which the peak of the 'hump' occurred was different for different proteins. For instance, the peak occurred at about $\mathrm{pH} 9 \cdot 30$ for $H_{\mathrm{II}}$ of chymotrypsin, but it was at about $\mathrm{pH} 9 \cdot 80,10 \cdot 25$ and $\mathbf{9 \cdot 8 5}$ respectively in the insulin, pepsin and plasma-albumin diagrams. 
Fig. $5 a$ shows the result of an experiment in which the cell contained $\mathbf{M}$-ammonium chloride, $0.001 \mathrm{M}$ cobaltic hexammine chloride and chymotrypsin at a concentration of $0.070 \mathrm{mg}$. $/ \mathrm{ml}$. The $\mathrm{pH}$ of the cell contents was altered by adding small volumes of $18 \mathrm{~N}$-sodium hydroxide or concentrated hydrochloric acid. Thus the only difference between the conditions in this experiment and the one represented by Fig. 4 is in the valence of the cobalt in the two cases, but in contrast to Fig. 4, the three curves in Fig. $5 a$ are quite flat in acid media. It was, in fact,
In no case was it possible to obtain a complete $\mathrm{pH}$ curve for wave I. At a high $\mathrm{pH}$ this wave becomes small and it is more or less merged with wave II.

\section{DISCUSSION}

The reactions which are responsible for the catalytic waves of proteins, cystine, cysteine and certain other mercaptans are not well understood, but cobalt and ammonia are necessary constituents of the electrolyte if waves I and II are to be recorded and this
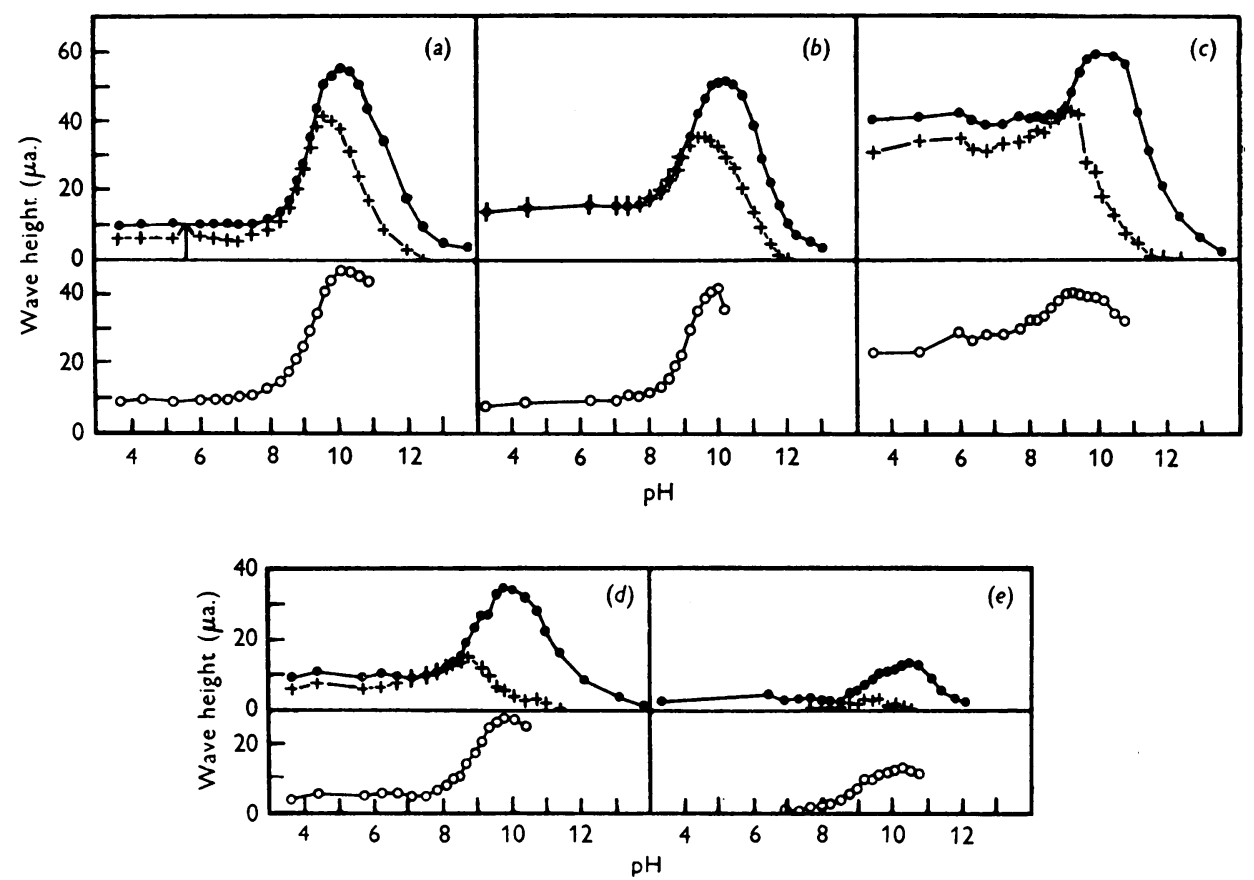

Fig. 5. Effect of electrolyte $\mathrm{pH}$ in the presence of trivalent Co on the polarographic waves of $(a)$ chymotrypsin, (b) chymotrypsinogen, $(c)$ insulin, $(d)$ pepsin, and $(e)$ egg albumin. For conditions see text. The method of measurement of $i_{a}$ is illustrated in $(a) . H_{\mathrm{I}}, \mathrm{O}-\mathrm{O} ; \mathrm{H}_{\mathrm{II}}, 0 ; H_{\mathrm{I} \text { min. }},+-+$.

a startling experience to record well developed protein waves in media as acid as $\mathrm{pH} 3 \cdot 7$. In electrolytes more acid than about $\mathrm{pH} \mathrm{3 \cdot 5}$, the true reduction wave of hydrogen ion distorts the protein record. In the trivalent cobalt medium it was possible to raise the $\mathrm{pH}$ to high values. This is not always feasible with bivalent cobalt for at a high $\mathrm{pH}$ there is an increasing tendency for the cobalt to precipitate.

Similar experiments were performed with crystal. line chymotrypsinogen, insulin, pepsin and egg albumin. The results are shown in Fig. $5(b-e)$. In each case the protein concentration was $0.070 \mathrm{mg}$./ ml., and the solution contained $M$-ammonium chloride and $0.001 \mathrm{~m}$-cobaltic hexammine chloride. leads to the supposition that a cobalt-ammonia complex must be an essential component of the system. The possibility that cobalt amalgam may lower the hydrogen overvoltage has not been excluded, but if this is the case it is difficult to identify the role of ammonia in the electrode processes unless it has a specific chemical effect on the protein or amino-acids or unless cobalt on the surface of the amalgam can form a complex with ammonia in the solution. The results are discussed, therefore, in relation to the electrode reactions which Brdička $(1933 b)$ has proposed to explain the catalytic waves.

Brdička $(1933 a, b)$ concluded that protein wave II is the result of the electrolytic reduction of hydrogen which is derived from sulphydryl groups 
since cystine or cysteine in ammoniacal cobalt solutions produce a single wave at the position of protein wave II. He suggested that, as a result of co-ordination binding between cobalt and sulphydryl, the hydrogen can be removed readily from the sulphur and is reduced at the cathode according to reaction (1):

$$
\mathrm{RSH}+e \rightarrow \mathrm{RS}^{-}+\mathrm{H} \text {. }
$$

He assumed that the sulphydryl anion reacts with water so that the sulphydryl group is regenerated leaving a hydroxyl ion which reacts with ammonium ion according to reactions (2) and (3):

$$
\begin{aligned}
& \mathrm{RS}^{-}+\mathrm{HOH} \rightleftarrows \mathrm{RSH}+\mathrm{OH}^{-}, \\
& \mathrm{NH}_{4}^{+}+\mathrm{OH}^{-} \rightleftarrows \mathrm{NH}_{3}+\mathrm{H}_{2} \mathrm{O},
\end{aligned}
$$

RSH which is regenerated may then participate in reaction (1) once more. The sulphydryl groups may come from the free side chains of cysteine residues in the protein, or they may arise from the polarographic reduction of cystine residues at a lower applied potential according to the following reaction:

$$
\mathrm{RSSR}+2 \mathrm{H}^{+}+2 e \rightarrow 2 \mathrm{RSH} .
$$

Brdička's pH studies (Brdička, 1936) are significant since the results constitute an important test of the current explanation of the origin of the polarographic protein waves, and yet these studies were applied to the 'prenatrium' wave rather than waves I and II, the waves which Brdička's three reactions were meant to explain. Furthermore, Brdička realized that an increase in the ammonia concentration should result in smaller waves $I$ and II according to reaction (3), yet he observed the reverse effect and Fig. 1 confirms his observation. In the case of cystine he attributed this enhancement to the adsorption of increased quantities of amino-acid on the electrode surface (Brdička, $1933 b$ ). The following equilibria and reactions are pertinent to the discussion:

$$
\mathrm{Co}\left(\mathrm{NH}_{3}\right)_{6}^{3+} \rightleftarrows \mathrm{Co}^{3+}+6 \mathrm{NH}_{3},
$$

$\mathrm{Co}\left(\mathrm{NH}_{3}\right)_{6}^{3+}+e \rightarrow \mathrm{Co}\left(\mathrm{NH}_{3}\right)_{6}^{2+}$ (first cobalt wave),

$$
\begin{gathered}
\mathrm{Co}\left(\mathrm{NH}_{3}\right)_{6}^{2+}+6 \mathrm{H}_{2} \mathrm{O} \underset{\text { rapid }}{\rightleftarrows} \mathrm{Co}\left(\mathrm{H}_{2} \mathrm{O}\right)_{6}^{2+}+6 \mathrm{NH}_{3}, \\
\mathrm{Co}\left(\mathrm{H}_{2} \mathrm{O}\right)_{6}^{2+} \rightleftarrows \mathrm{Co}^{2+}+6 \mathrm{H}_{2} \mathrm{O},
\end{gathered}
$$

$\mathrm{Co}\left(\mathrm{H}_{2} \mathrm{O}\right)_{6}^{2+}+2 e \rightarrow \mathrm{Co}+6 \mathrm{H}_{2} \mathrm{O}$ (second cobalt wave),

$$
\mathrm{RSH}+e \stackrel{\mathrm{Co}\left(\mathrm{NH}_{3}\right)_{6}^{2+}}{\longrightarrow} \mathrm{RS}^{-}+\mathrm{H} \text { (protein wave), }
$$

$$
\begin{aligned}
& \mathrm{RS}^{-}+\mathrm{H}^{+} \rightleftarrows \mathrm{RSH}, \\
& \mathrm{NH}_{4}^{+} \rightleftarrows \mathrm{NH}_{3}+\mathrm{H}^{+} .
\end{aligned}
$$

Protein waves I and II can be obtained in an ammonia buffer if the electrolytic cell contains either cobaltous chloride or cobaltic hexammine chloride. Reaction (5) represents the dissociation equilibrium of the cobaltic hexammine ion. This is a very stable complex with a dissociation constant of $2.2 \times 10^{-34}$ (moles/l. $)^{6}$ according to Lamb \& Larson (1920). In the polarographic cell this ion produces a wave at about $-0 \cdot 4 \mathrm{~V}$. referred to the saturated calomel electrode (s.c.E.) (Willis, Friend \& Mellor, 1945). The electrode reaction is represented in reaction (6). Such a solution will contain no cobaltous hexammine ion except that which is 'deposited' at the electrode by the reduction of the trivalent ion. The bivalent complex is distinguished from the trivalent complex by its instability, for Lamb \& Larson (1920) concluded that its dissociation constant is of the order of $1.25 \times 10^{-5}(\mathrm{moles} / 1 .)^{6}$. This means that its dissociation curve lies almost entirely between $\mathrm{pH} 8$ and 9 . The dissociation is represented in reaction (7). Reaction (7) moves to the left when cobaltous chloride is added to an ammonia buffer so that it is apparent that the $\mathrm{pH}$ of the medium will determine the concentration of cobaltous hexammine ion in the bulk of the solution in this case. The hydrated cobalt ion which is in close proximity to the mercury drop is reduced according to reaction (9) (Willis et al. 1945), to produce the second cobalt wave. The consequent lowering of the concentration of hydrated ion will draw reaction (7) to the right and the bivalent ammonia complex will dissociate in the neighbourhood of the drop. The dissociation is apparently rapid since the second cobalt wave is twice the height of the first cobalt wave. Brdička (1933a) stated that the second cobalt wave is preceded by a very small wave which he attributed to the reduction of free bivalent cobalt ions which are represented in reaction (8). Because the wave is small, the dissociation of the hydrated complex must be slow. Reactions (10), (11) and (12) represent a slight revision of the reactions which Brdička $(1933 b)$ proposed to explain the catalytic protein waves I and II. Co-ordinate bonding between the cobalt of the cobaltous hexammine ion and mercaptan sulphur allows the hydrogen to be removed and reduced (reaction 10). The sulphydryl group is restored through reaction (11) and the group may then enter into reaction (10) once more. The objection may be put forward that reaction (11) does not differ from the combined effect of reactions (2) and (3) and this is true, since in either case the hydrogen ion must be supplied from the water through the action of the buffer. The advantage in reactions (10) and (11) lies in the fact that they place emphasis on the role of ammonia in the maintenance of a supply of cobalt-ammonia complex. In parenthesis it should be noted that we still have no explanation for the observation of Brdička $(1933 a, b)$, that whereas protein polarograms can be recorded from ammoniacal solutions containing 
either bivalent or trivalent cobalt, cystine and cysteine catalytic waves can be produced only from ammoniacal solutions containing bivalent cobalt.

Reaction (12) represents the ammonia buffer equilibrium. It has a pK of $9 \cdot 26$.

If we assume that reaction (5) is essentially independent of $\mathrm{pH}$, then the hydrogen-ion concentration of the buffer can affect this scheme only at reactions (7) and (11). When the $\mathrm{pH}$ is raised the protein current will tend to be depressed since the regeneration of sulphydryl groups (reaction 11) will be hindered. On the other hand, the resultant increase in ammonia concentration will tend to force reaction (7) to the left so that there will be a greater probability of sulphydryl activation by cobaltous hexammine ion. It seemed conceivable that if protein polarograms were recorded over a wide range of $\mathrm{pH}$ the wave heights might be limited by reaction ( 7 ) in media with $\mathrm{pH}$ values below 9 , and by reaction (11) in media of some higher $\mathrm{pH}$ value. Cannan (1942) has suggested that the sulphydryl groups in proteins may have a pK of about 10 .

In the electrolyte which contained bivalent cobalt the $\mathrm{pH}$ curves always showed a definite positive slope when the $\mathrm{pH}$ was low, and this behaviour is accepted as evidence that the wave height is limited by reaction (7) in this $\mathrm{pH}$ range. In such a system reactions (5) and (6) are not present, and the concentration of cobaltous hexammine ion depends on the $\mathrm{pH}$ of the medium through reactions (7) and (12). At low pH the rate of supply of this complex to the electrode will be low because there will be only a fraction of the total cobalt in this form. As the $\mathrm{pH}$ is raised and a greater proportion of the cobalt assumes the hexammine form larger waves would be anticipated. It was expected that this portion of the curve might become flat if cobaltic hexammine chloride was used, because the reduction of the trivalent complex ion would supply bivalent complex ions to the electrode surface at a constant rate which would be determined by the initial concentration of trivalent ion and its diffusion constant. This expectation was realized in the experiments represented by Fig. 5. Presumably most of the bivalent complex dissociates (reaction 7) to provide hydrated complex which is reduced according to reaction (9), while some of the bivalent complex co-ordinates with mercaptan to provide activation for reaction (10).

According to this viewpoint it might be expected that the wave height would drop close to zero below pH 8 in a bivalent cobalt solution since the dissociation curve of cobaltous hexammine ion lies almost completely between pH 8 and pH 9. However, it must be realized that the $\mathrm{pH}$ determinations refer to the $\mathrm{pH}$ of the bulk of the solution, whereas the wave heights depend upon the pH of a thin layer of solution which surrounds the cathode. This thin layer of solution may be referred to as the reaction layer. When the bulk of the electrolyte has a $\mathrm{pH}$ value which lies within the functional range of the ammonia buffer ( $\mathrm{pH} 7 \cdot 25-11 \cdot 25$ approximately), the $\mathrm{pH}$ of the reaction layer is probably close to the Beckman pH-meter reading, but beyond the effective range of buffer the $\mathrm{pH}$ of the reaction layer is probably always higher than the Beckman reading. This is because the electrode process removes hydrogen ions from this volume and at the same time six ammonia molecules are set free at the electrode surface for every cobalt ion reduced. The $\mathrm{pH}$ of the reaction layer does not rise indefinitely, however, since the components of a buffer are present. Ammonia probably diffuses away from the drop and ammonium ion probably diffuses to it until an equilibrium has been attained. The final $\mathrm{pH}$ of the reaction layer will depend on the diffusion constants of these buffer components, on their concentrations in the bulk of the electrolyte, on the rate of liberation of ammonia from cobalt complexes and on the protein current itself, which removes hydrogen ions. It would be expected to vary from wave to wave. The fact that the wave heights do not fall to zero in electrolytes having $\mathrm{pH}$ less than 8 simply means that the alkaline conditions in the reaction layer force reaction (7) to the left and provide some of the bivalent complex in this region even though there may be very little in the bulk of the solution. When the cobaltic hexammine salt is used it seems likely that when the pH of the bulk is neutral or acid, the $\mathrm{pH}$ of the reaction layer is indicated by the $\mathrm{pH}$ at which the curves cease to be linear. For instance, in Fig. $5 a$ the pH of the reaction layer was about $6 \cdot 75$ when wave I was recorded from media with $\mathrm{pH}$ values more acid than this. Similarly, the $\mathrm{pH}$ of the reaction layer was about $7 \cdot 5$ when $H_{\mathrm{II}}$ and $H_{\text {I min. }}$ were recorded, although the bulk of the cell contents was much more acid.

The $\mathrm{pH}$ curve of wave $\mathrm{I}$ of insulin is not flat in neutral or acid media (Fig. $5 c$ ). This deviation from the usual response cannot be explained, but it may be related in some manner to the high cystine content of insulin or to the dissociation of insulin which is said to occur when the $\mathrm{pH}$ is raised (Gutfreund, 1948; Millar, 1953).

The same general pattern is observed in all these charts, yet each shows individual differences which must be related to the physical and chemical characteristics of the individual proteins. The most obvious differences are in the magnitude of the current throughout the flat portions of the curves. This measurement will be referred to by the symbol $i_{a}$. Another obvious difference between charts is the position of the peak of the 'hump' on the $\mathrm{pH}$ scale and, lastly, the magnitude of the current at the peak of the 'hump'. 
An attempt was made to learn something of the factors which determine the shape of the $\mathrm{pH}$ curves by plotting these characteristics of the $\mathrm{pH}$ curves against the amino-acid content of the proteins. In certain cases a correlation has been found. Excessive weight cannot be placed upon these correlations, because some of the data are no more than approximate. Nevertheless, all these plots point in one direction and they are, therefore, suggestive.

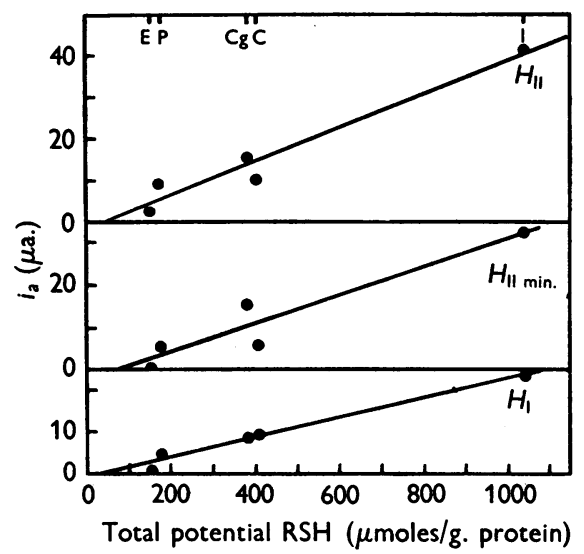

Fig. 6. The relation between $i_{a}$ and the total potential sulphydryl content of five proteins. $i_{a}$ is the wave height obtained in electrolytes of relatively acid $\mathrm{pH}$ as shown in Fig. 5. E, P, Cg, C and I refer to egg albumin, pepsin, chymotrypsinogen, chymotrypsin and insulin respectively.

In Fig. 6, the various values for $i_{a}$ have been plotted against the 'total potential RSH' of each of the proteins as defined in the first paper of this series (Millar, 1953). This aggregate figure is used because the polarograph does not distinguish between cysteine sulphydryl groups and those groups which arise from the reduction of cystine. The straight lines are best fits calculated by the method of least squares.

Fig. 6 shows that there is a strong correlation between $i_{a}$, the height of the level portion of the $\mathrm{pH}$ curve, and the potential sulphydryl content of these proteins. This is particularly true of the $i_{a}$ of $H_{\mathrm{I}}$ and yet certain difficulties arise when we try to explain this linearity. Such a relationship is possible only because, in each experiment, the same concentration of protein was used in each case, namely, $0.070 \mathrm{mg} . / \mathrm{ml}$. This condition, in fact, converts the abscissa into a sulphydryl concentration scale if we look upon the protein simply as a carrier of mercaptan. For instance, the total potential RSH content of insulin is $1.04 \mathrm{~m}$-moles $/ \mathrm{g}$. of protein (Tristram, 1949) so the concentration of potential $\mathrm{RSH}$ in the solution was $0.0728 \mu \mathrm{moles} / \mathrm{ml}$. solution. If this viewpoint is valid then we conclude that $i_{a}$ is linearly related to the concentration of potential
RSH in the solution. The diffusion current of metal ions and many organic compounds is usually directly proportional to the concentration of reactive ion also, but since the RSH of the protein is probably not eliminated at the electrode, but is being continually regenerated there, it is doubtful if the rate of diffusion of the protein 'carrier' limits the current. Nor can the linearity be explained by assuming that the quantity of protein adsorbed on the electrode is proportional to the potential RSH content. This would lead to a parabolic relationship. The conclusion that seems most likely is that approximately the same quantity of protein is adsorbed on unit area of the electrode no matter which protein is being used and that either all of the potential RSH groups in each protein react at the drop or that a certain fixed proportion, say $50 \%$, of the groups of each protein is involved in the reaction. Under a given set of experimental conditions with respect to buffer and cobalt concentration and at low electrolyte $\mathrm{pH}$, the current would be limited by the rate of diffusion of hydrogen ions except for the fact that the electrode process causes the $\mathrm{pH}$ of the reaction layer to rise until the buffering properties of the electrolyte are encountered. The greater the number of potential RSH groups available, the greater is the rate of discharge of hydrogen ions and the more closely does the $\mathrm{pH}$ of the reaction layer approach the $\mathrm{pK}$ of the buffer. Thus adequate quantities of hydrogen ions are supplied to support the electrode reaction.

Certain objections can be raised against this proposal which cannot be answered yet. Denaturation of a protein usually enhances its polarographic waves (Wenig \& Jírovec, 1938). This phenomenon is usually explained as being due to a 'release' of previously unreactive sulphydryl groups. This explanation is not valid if all the potential sulphydryl groups are active in the untreated protein, and there is certainly no evidence to support the view that a certain fixed proportion of the potential groups of different proteins are more reactive than the remainder. However, it must be emphasized that the polarograms we are concerned with here were recorded under special conditions while all the denaturation studies involved electrolysis at conventional values of electrolyte $\mathrm{pH}$ fixed in the neighbourhood of 9.3. If it were found that denaturation of a protein shifted its $\mathrm{pH}$ curve toward more acid values, enhancement of the waves by denaturation could be explained without postulating the existence of polarographically inactive sulphydryl groups in the untreated protein.

It is probable that the protein adsorbed on the drop is denatured to some degree because of the spreading and the alkaline environment. It may be that this denaturation contributes to the linearity of the data. 
Fig. 6 implies that the 'turnover number', the number of reactions in which a single sulphydryl group participates in 1 sec., is a constant for different proteins. This seems reasonable, but there has been no previous evidence on this question one way or the other.

The results portrayed in Fig. 6 invite further investigation. If a linear relationship holds for a wide range of protein concentrations and for mixtures of different proteins, it may be of some analytical value, for a very simple procedure would be required. Since trivalent cobalt is used, an ammonia buffer is not essential and there might be some advantages is using other buffers. If further

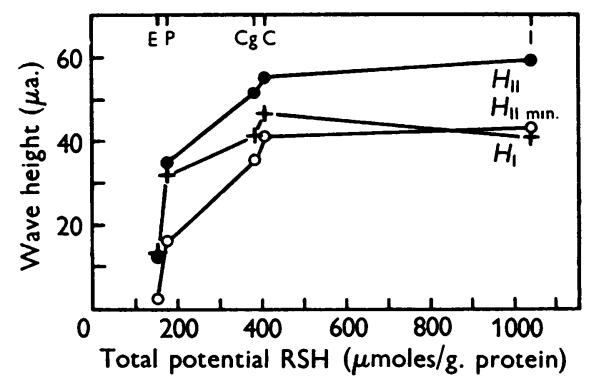

Fig. 7. The relation between the magnitude of the wave height at optimal $\mathrm{pH}$ (see Fig. 5) and the total potential sulphydryl content of five proteins. $\mathrm{E}, \mathrm{P}, \mathrm{Cg}, \mathrm{C}$ and I refer to egg albumin, pepsin, chymotrypsinogen, chymotrypsin and insulin respectively.

studies confirm this result it will be the first time that the height of any of the protein waves has been correlated quantitatively with the chemical composition of the protein. Further attempts to correlate $i_{a}$ with the amino-acid contents of these proteins were not successful.

In Fig. 7, the magnitude of the current at the peak of the 'hump' is plotted against the total potential RSH of each protein. These curves bear a resemblance to the wave height-protein concentration curves that are obtained in the usual ammonia buffer at constant electrolyte $\mathrm{pH}$ in the neighbourhood of pH 9.2-9.5 (Millar, 1953). A comparison of Figs. 6 and 7 suggests $(a)$ that the electrode reactions are different within these two $\mathrm{pH}$ ranges, or ${ }^{\prime}(b)$ that the large current at high $\mathrm{pH}$ causes some component of the system to be depleted so that it limits the current.

In Fig. 8, the pH at which the peak of the 'hump' occurs is plotted against the aggregate arginine and lysine content of the proteins (Tristram, 1949). Analytical values for the lysine content of chymotrypsin could not be found, so only four proteins are represented. There seems to be a fair correlation between these two variables except in the case of wave I. The same statement may be made when the
$\mathrm{pH}$ of the peak is plotted against the number of free amino groups/mole of protein, although even less weight can be given to this observation since there are analytical data available for only three of the five proteins. There is some degree of correlation between the $\mathrm{pH}$ of the peak and the tyrosine content of the proteins (Tristram, 1949). It seems to be best in the case of wave $I$ (Fig. 8).

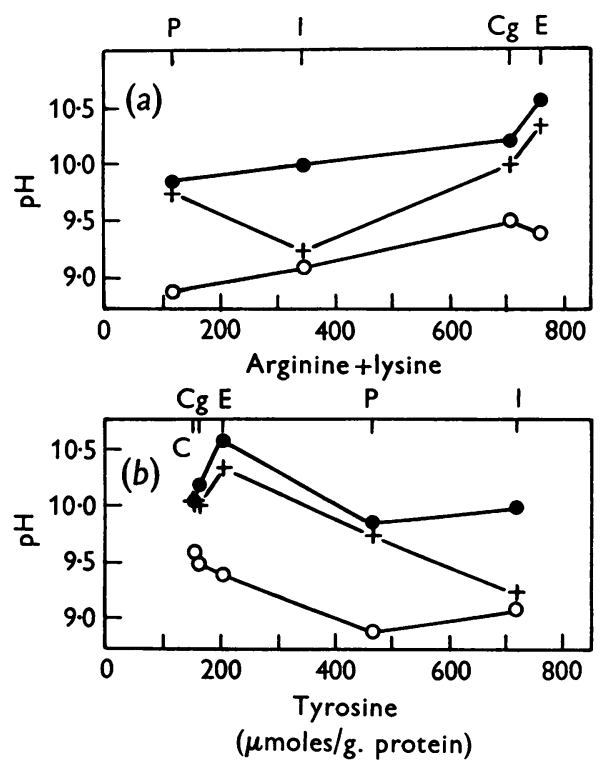

Fig. 8. The relationship between the optimal electrolyte $\mathrm{pH}$ and the content of $(a)$ arginine +lysine, $(b)$ tyrosine residues in some proteins. $\mathrm{P}, \mathrm{I}, \mathrm{Cg}, \mathrm{C}$ and $\mathrm{E}$ refer to pepsin, insulin, chymotrypsinogen, chymotrypsin and egg albumin respectively. $H_{1},+-+; H_{\mathrm{II}},-$; $H_{\text {II min. }}$ O-O.

It is not possible to determine with a high degree of accuracy the $\mathrm{pH}$ at which the $\mathrm{pH}$ curves attain their maximum value, but it is probably safe to conclude that the higher the proportion of basic groups and the lower the proportion of tyrosine groups in a given protein, the greater is the likelihood that the $\mathrm{pH}$ curve of that protein will have a maximum value at a high $\mathrm{pH}$. It is interesting to note in this connexion that the tyrosine side chain, in its ionized form, has a negative charge, while the ionized forms of the side chains of arginine and lysine have a positive charge.

A second objective of this work was to determine whether the current would be limited by the rate of regeneration of sulphydryl groups (reaction 11) when the $\mathrm{pH}$ of the electrolyte is high. If, at high $\mathrm{pH}$, the current fell from the $i_{a}$ level along a conventional dissociation curve, there would be some justification for saying that the current was limited by reaction (11) since a correlation had been found 
between $i_{a}$ and the total potential RSH content of the protein. The question is made more complicated by the appearance of the 'hump' on the pH curve. It is not surprising to find that the heights of the waves are enhanced when the $\mathrm{pH}$ of the electrolyte is in the neighbourhood of the $\mathrm{pK}$ of the buffer system, for in such circumstances the electrolyte can supply hydrogen ions at a maximal rate for the regeneration of sulphydryl groups. However, it is surprising to find that the peaks of the 'humps' are all on the alkaline side of the pK of the buffer $(\mathrm{pK}=9 \cdot 26)$. To show that this discrepancy was not due to instrumental errors, the individual volumes of $18 \mathrm{~N}$-sodium hydroxide which had been added to the cell were divided by the increment of $\mathrm{pH}$ which

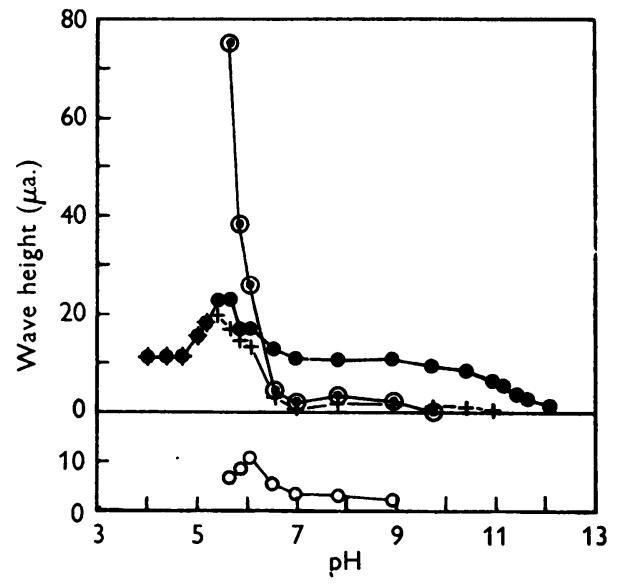

Fig. 9. Effect of electrolyte $\mathrm{pH}$ on the polarographic waves of insulin with sodium acetate buffer. For conditions see text. $H_{\mathrm{I}}, \mathrm{O}-\mathrm{O} ; H_{\mathrm{II}}, \bigcirc ; H_{\mathrm{II} \text { min. }},++$; $H_{\mathrm{III}}, \odot-\odot$.

each had produced and the quotients were plotted against a pH scale. The resultant curves were not smooth because of the strength of the base and the small volumes that were added, but it was clear that all five curves had maximum values that were close to $\mathrm{pH} 9 \cdot 26$. These curves, which are a measure of the buffering power of the system, are the $\beta$ curves of Van Slyke (1922).

If the 'hump' appeared on the acid side of the buffer pK the phenomenon might be explained as follows. Since the reaction layer is more alkaline than the bulk of the solution, the peak of the buffer $\beta$ curve was attained in the reaction layer when the $\mathrm{pH}$ of the bulk of the solution was below the $\mathrm{pK}$ value. Since the current rose on the acid side of electrolyte buffer $\mathrm{pK}$, the current must depend upon the $\beta$ of the buffer. However, the hump actually occurs on the alkaline side of the buffer pK. The above argument might therefore be used to show that the current is not directly dependent on

Biochem. 1953, 53 the buffer $\beta$, but this does not constitute an explanation for the position of the 'hump'.

The 'hump' seems to be superimposed on the sulphydryl dissociation curve which would be anticipated by our hypothesis in its simplest form. The 'hump' is not a simple buffer $\beta$ curve, and yet the buffering power of the system is involved in its formation as the following experiment demonstrates (Fig. 9). Here the cell contained sodium acetate $(0 \cdot 1 \mathrm{M})$, cobaltic hexammine chloride $(0.001 \mathrm{M})$ and insulin $(0.070 \mathrm{mg} . / \mathrm{ml}$.). The solution was made alkaline to $\mathrm{pH} 12 \cdot 1$ by the addition of an appropriate amount of $18 \mathrm{~N}$-sodium hydroxide, then

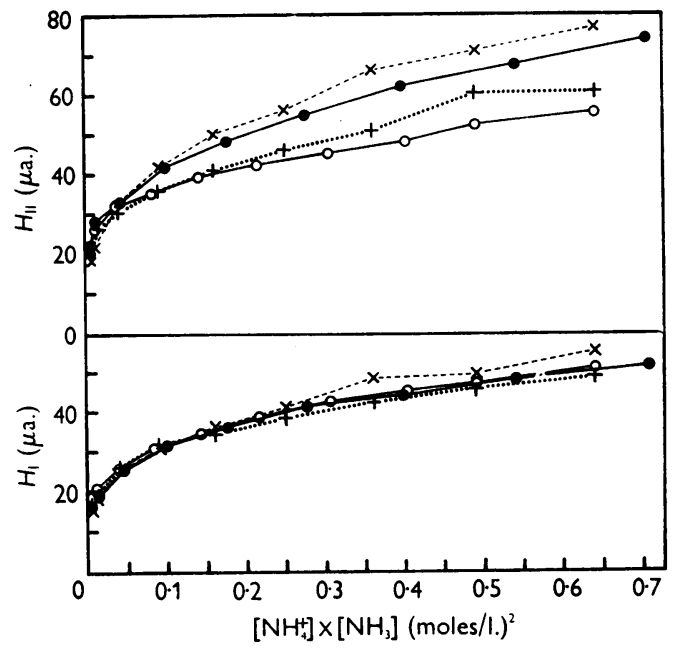

Fig. 10. The relation of the product of the concentrations of the buffer components to the heights of waves I and II of bovine albumin for four values of electrolyte $\mathrm{pH}$. Conditions and symbols as in Fig. 1 .

polarograms were recorded at various stages as the pH was lowered by additions of concentrated hydrochloric acid. (Fig. 9 includes the response of protein wave III as well as the other three $\mathrm{pH}$ curves.) The pK of the acetate buffer is 4.75 and the 'hump' of each pH curve occurred on the alkaline side of the buffer pK. At higher $\mathrm{pH}, H_{\mathrm{II} \text { min. }}$ fell to zero, but $H_{\mathrm{II}}$ maintained its height up to about pH $9 \cdot 0$, although the bulk of the electrolyte was not buffered at $\mathrm{pH}$ values higher than about $6 \cdot 75$. However, the reaction layer surrounding the electrode was probably buffered to some extent by an ammonia buffer, since ammonia was liberated there by the reduction of the trivalent cobalt complex. At $\mathrm{pH}$ values higher than 9.0 or $9 \cdot 25, H_{\mathrm{II}}$ fell toward zero. These curves show that a 'hump' is associated with the buffer system and that it does not depend on any specific properties of ammonia or ammonium ion. The decrease of $H_{\mathrm{II}}$ at high $\mathrm{pH}$ is probably due to interference with the hydrogen-ion 
supply and is attributed, for the present, to reaction (11). This terminal decrease does not follow a simple dissociation curve. Presumably the influence of the ammonia buffer in the reaction layer complicates the relationship.

Numerous attempts have been made to reconstruct the $\mathrm{pH}$ curves by combining $(a)$ a dissociation curve of maximum height equal to $i_{a}$ with $(b)$ one or more $\beta$ curves or $\beta$ curves which were raised to a power. Limited success has attended these efforts, but the work has suggested a superior technique for studying the effect of $\mathrm{pH}$ on the protein curves. In Fig. 10 the heights of waves I and II as reported in section $\mathbf{A}$ have been plotted against the product $\left[\mathrm{NH}_{4}^{+}\right]\left[\mathrm{NH}_{3}\right]$. The product is proportional to the $\beta$ value of an ammonia buffer of total molarity equal to unity (Van Slyke, 1922). Such a plot of a family of curves over a wide range of $\mathrm{pH}$ would give the response of the protein waves to variations of $\mathrm{pH}$ when the buffering power of the system is constant. Such a technique also circumvents the question of ionic strength which was not controlled in the present study.

\section{SUMMARY}

1. An investigation has been made of $(a)$ the effect of electrolyte $\mathrm{pH}$ upon the first two polarographic protein waves of five crystalline proteins when the total molarities of the ammonia buffer and cobalt were maintained constant, and $(b)$ the effects upon the three polarographic protein waves of crystalline bovine plasma albumin of varying the concentrations of ammonia and of ammonium ion at nearly constant electrolyte $\mathrm{pH}$.

2. Under the conditions of $1(a)$, the wave heights rose when the electrolyte $\mathrm{pH}$ was raised from about $\mathrm{pH} 3.5$ to 8.5 if bivalent cobalt was used. When trivalent cobalt was used the wave heights in neutral and acid media $\left(i_{a}\right)$ were quite constant. It is concluded that the enhancement in bivalent cobalt solutions is due to the concomitant increase in concentration of cobaltous hexammine ion.

3. There is a strong correlation between $i_{a}$ and the total potential sulphydryl content of these proteins. This is the first time that a quantitative relationship has been shown between protein waves $I$ and II and the amino-acid composition of a protein.
4. A satisfactory explanation of this relationship cannot be offered, but it implies that all the potential sulphydryl groups of the protein may be reactive in acid media.

5. In media poised at neutral or acid $\mathrm{pH}$, the $\mathrm{pH}$ of the solution layer surrounding the mercury drop (the reaction layer) is probably more alkaline than the bulk of the electrolyte. In a trivalent cobalt solution the $\mathrm{pH}$ of the reaction layer is indicated by the $\mathrm{pH}$ wave height curve of a particular protein.

6. The protein waves are enhanced when the $\mathrm{pH}$ of the electrolyte is in the neighbourhood of the $\mathrm{pK}$ of the buffer system and they attain a maximum value on the alkaline side of the buffer pK. At high $\mathrm{pH}$ the waves are depressed.

7. The $\mathrm{pH}$ at which the maximum wave height occurs seems to depend upon the tyrosine content and the arginine plus lysine content of the protein. The magnitude of the maximum wave height is related to the total potential sulphydryl content of the protein but the relationship is not linear.

8. Certain evidence is tentatively interpreted to mean that at high electrolyte $\mathrm{pH}$ the wave height is limited by the dissociation of sulphydryl groups.

9. Under the conditions of 1 (b) waves I and II are enhanced $(a)$ when the total molarity of the buffer is increased, or $(b)$ when the concentration of one of the buffer components is maintained constant and the other is increased. Under these conditions the wave heights are independent of $\mathrm{pH}$ in the range $8 \cdot 7-9 \cdot 5$.

10. Brdička's observations on the effect of $\mathrm{pH}$ on wave III, the 'prenatrium' wave, have been confirmed for conditions of low buffer molarity. The effect seems to be more complex when the buffer concentration is high.

11. The reactions and equilibria responsible for the effects are discussed, emphasis being laid on the importance of cobaltous hexammine ion in the catalytic reactions.

The author wishes to express his gratitude to the National Research Council of Canada for its support of these investigations. He is also indebted to $\mathrm{Dr} \mathrm{K}$. McCallum, Department of Chemistry, University of Saskatchewan, for the constructive criticism he has offered during the course of this study, and to Dr D. Y. Solandt, University of Toronto, and Dr L. B. Jaques for their interest and support.

\section{REFERENCES}

Brdička, R. (1933a). Coll. Trav. chim. Tchécosl. 5, 112. Brdička, R. (1933b). Coll. Trav. chim. Tchécosl. 5, 148. Brdička, R. (1936). Coll. Trav. chim. Tchécosl. 8, 366.

Cannan, R. K. (1942). Chem. Rev. 30, 395.

Gutfreund, H. (1948). Biochem. J. 42, 544.

Heyrovský, J. \& Babička, J. (1930). Coll. Trav. chim. Tchécosl. 2, 370.

Jurka, E. (1939). Coll. Trav. chim. Tchécosl. 11, 243.
Lamb, A. B. \& Larson, A. T. (1920). J. Amer. chem. Soc. 42, 2024.

Millar, G. J. (1953). Biochem. J. 53, 385.

Tristram, G. R. (1949). Advanc. Protein Chem. 5, 83.

Van Slyke, D. D. (1922). J. biol. Chem. 52, 525.

Wenig, K. \& Jírovec, O. (1938). Biochem. Z. 295, 405.

Willis, J. B., Friend, J. A. \& Mellor, D. P. (1945). J. Amer. chem. Soc. 67, 1680. 